\title{
Penerapan Manajemen Risiko pada Tingkat Efisiensi Keuangan di Bank DKI Jakarta
}

\author{
Saridawati ${ }^{*}$, Murniyati ${ }^{2}$, Ratih Hastasari ${ }^{3}$, Suharini $^{4}$ \\ Universitas Bina Sarana Informatika ${ }^{1234}$ \\ saridawati.sti@bsi.ac.id, murni.mni@bsi.ac.id, ratih.rhs@bsi.ac.id, $\underline{\text { suharini.suh@bsi.ac.id }}$
}

*Penulis Korespondensi

Diajukan : 5 Maret 2021

Diterima $\quad$ : 9 Mei 2021

Dipublikasi : 1 Agustus 2021

\begin{abstract}
Efficiency is one measure of bank performance. The efficiency of a bank is influenced by the way management manages risk. Financial services authority regulation number 18 /pojk.03/2016 issued by Bank Indonesia which requires every bank in Indonesia to form a risk management team. Risk management problems in the banking world are related to the losses they experience, and Regional Development Banks are expected to be able to detect maximum losses that may arise in the future. This team is obliged to control various aspects of risk management in each bank and observe the impact of risk management implementation. This study aims to determine the efficiency level of conventional banking at PT Bank Pembangunan Daerah Jawa Tengah and the effect of financing risk, operational risk and liquidity risk on the efficiency level. Efficiency is measured by the method of Operating Expenses from Operating Income. The data used as the object of this research is Bank DKI Jakarta for the 2015-2020 period. The level of influence of the variables XI, $X 2, X 3$ on $Y$ on the determinant coefficient $(R 2)$ shows the Adjusted $R$ Square number of 0.359 or $35.9 \%$ which means that the variation in efficiency level can be explained by financing risk, operational risk and liquidity risk, the remaining $64.1 \%$ can be explained from other variables outside, for previous related studies there is no similarity in the influence of independent $(x)$ and dependent $(Y)$ values, because of differences in values generated from SPSS processing data. Based on the results of statistical tests and discussion analysis, it is known that financing risk, operational risk, liquidity risk simultaneously have no effect on the level of efficiency and only financing risk has a significant positive effect on the level of efficiency at PT Bank DKI Jakarta.
\end{abstract}

Keywords: Financing Risk, Operational Risk, Liquidity Risk, Financial Efficiency

\section{PENDAHULUAN}

Bank memberikan kredit dengan risiko tertentu kepada warga, sehingga dalam penerapannya bank dituntut untuk memperhatikan prinsip perkreditan yang sehat(Eprianti, 2019). Bank Pembangunan Daerah (BPD) merupakan salah satu lembaga keuangan yang menjadi pusat persatuan daerah dalam mewujudkan pembangunan ekonomi(Sukamto, 2016). Kondisi perbankan saat ini yang kinerjanya baik dipengaruhi oleh seluruh BPD di Indonesia(Nazir, 2018). Hal tersebut dibuktikan dengan peningkatan kinerja dan kesehatan bank pembangunan pada tahun 2015. Ratarata kinerja Bank Pembangunan Daerah mencapai 2,77\% yang menjadi penyumbang terbesar pertumbuhan perbankan di Indonesia yang tumbuh sekitar 25,7 persen jika dibandingkan dengan tahun yang sama periode tahun sebelumnya. (Nazir \& Mahfuzah, 2018), Bank Pembangunan Daerah perlu menerapkan manajemen risiko untuk meningkatkan kinerja menjadi lebih baik (Riau, 2017). Peraturan otoritas jasa keuangan nomor 18 /pojk.03/2016 yang dikeluarkan Bank Indonesia yang meminta setiap bank di Indonesia membentuk tim manajemen risiko. Tim ini berkewajiban untuk mengontrol berbagai aspek manajemen risiko di masing-masing bank dan mencermati dampak penerapan manajemen risiko, khususnya terhadap kekuatan moneter di Indonesia(Gustiawan, 2019). Permasalahan manajemen risiko di dunia perbankan terkait dengan kerugian yang dialaminya, serta Bank Pembangunan Daerah diharapkan mampu mendeteksi secara 
maksimal kerugian yang mungkin timbul dimasa yang akan datang(Chosyali \& Sartono, 2019). Penerapan manajemen risiko pada Bank Pembangunan Daerah khususnya risiko kredit, alat analisis yang digunakan adalah Non Performing Loan (NPL), yaitu perbandingan kredit bermasalah terhadap total kredit. NPL yang tinggi akan mengganggu peredaran dana Bank Pembangunan Daerah sehingga menyebabkan kinerja Bank Pembangunan Daerah mengalami penurunan (Amalina \& Saifi, 2018). Hasil terjemahan pengukuran kinerja perbankan juga dilakukan dengan menggunakan rasio likuiditas yang disebut Loan to Deposit Ratio (LDR), yaitu rasio pinjaman terhadap dana pihak ketiga dan dana pihak ketiga. Semakin tinggi LDR maka semakin tinggi pula laba bank, seiring dengan peningkatan laba bank maka kinerja bank juga meningkat. LDR berpengaruh terhadap kinerja perbankan. Selanjutnya penerapan manajemen risiko dalam penelitian ini yang digunakan adalah Rasio Beban Operasional terhadap Pendapatan Operasional (BOPO), yaitu untuk mengukur kemampuan manajemen Bank Pembangunan Daerah dalam mengendalikan biaya operasional terhadap pendapatan operasional(Kansil et al., 2017) .

BOPO yang tinggi menunjukkan ketidakefisienan Bank Pembangunan Daerah dalam menjalankan operasinya sehingga mempengaruhi kinerja Bank Pembangunan Daerah (Nazir, 2018). Efisiensi adalah hal mendasar konsep dan lahir dari konsep ekonomi tingkat efisiensi bank merupakan ukuran seberapa besar kemampuan bank dalam menjalankan kegiatan operasionalnya. Rasio keuangan yang digunakan untuk mengukur tingkat efisiensi bank adalah BOPO (Pengeluaran operasional terhadap pendapatan operasional). Operasional pengeluaran adalah bagi hasil diberikan kepada pelanggan dan pendapatan operasional bagi hasil diperoleh dari pelanggan. Semakin kecil nilai BOPO berarti semakin banyak. bank yang efisien beroperasi(Alimusa \& Murini, 2018). Risiko. manajemen sebagai proses yang komprehensif menyentuh hampir setiap aspek dari aktivitas suatu badan usaha, mulai dari proses pengambilan keputusan untuk menginvestasikan sejumlah uang, hingga keputusan untuk mempekerjakan karyawan baru (Suwinardi, 2016). Tujuan dari manajemen risiko adalah untuk mencegah atau meminimalkan dampak buruk yang ditimbulkan dari kejadian yang tidak terduga dengan cara menghindari risiko atau menyusun rencana kontinjensi terkait risiko tersebut(Senduk, Willar, \& Manoppo, 2016). Penerapan manajemen risiko pada bank memiliki peran yang sangat besar dalam meningkatkan nilai pemegang saham melalui penerapan strategi bisnis berbasis risiko. Manajemen risiko memberikan gambaran kepada pengelola bank mengenai potensi kerugian di masa depan, serta memberikan informasi untuk mengambil keputusan yang tepat sehingga dapat membantu pengelola bank dalam meningkatkan daya saing (Mukhlishin \& Suhendri, 2018).

Penelitian dilakukan pada Bank DKI merupakan Bank Umum dan Badan Usaha Milik Daerah yang kepemilikan sahamnya dimiliki oleh Pemerintah Provinsi DKI Jakarta dan PD Pasar Jaya. Akta Perseroan Terbatas Perusahaan Bank Pembangunan Daerah Djakarta Raya (PT Bank Pembangunan Daerah Djakarta Raya) No. 30 tanggal 11 April 1961 dibuat oleh dan dihadapan Eliza Pondaag S.H., Notaris di Jakarta (DKI, 2021).

\section{Penelitian Terdahulu}

\section{STUDI LITERATUR}

Tujuan penelitian ini adalah untuk menguji pengaruh Non Performing Loan (NPL), Net Interest Margin (NIM), Loan to Deposit Ratio (LDR) dan Biaya Operasional Pendapatan Operasional (BOPO) terhadap Return on Assets (ROA) pada Pembangunan Daerah. Bank (BPD) di Indonesia. Data yang digunakan dalam penelitian ini adalah data NPL, NIM, LDR, BOPO dan ROA dari BPD di Indonesia dari tahun 2011 sampai 2016 yang diakses melalui website www.ojk.go.id. Metode analisis data dalam penelitian ini adalah analisis regresi linier berganda. Hasil penelitian menemukan bahwa NPL dan NIM berpengaruh tidak signifikan terhadap ROA, sedangkan LDR dan BOPO berpengaruh negatif (Nazir, 2018)

Sedangkan penelitian selanjutnya menganalisis Pengaruh Penerapan Manajemen Risiko Terhadap Kinerja Keuangan Dengan Dimoderasi Good Corporate Governance (Studi Empiris Pada BPD Se-Indonesia Tahun 2009-2013). Variabel independen yang digunakan dalam penelitian ini adalah penerapan manajemen risiko yang diwakili oleh manajemen risiko kredit (NPL), manajemen risiko likuiditas (LDR), dan manajemen risiko operasional (BOPO), sedangkan variabel dependen yang digunakan dalam penelitian ini adalah kinerja keuangan Bank 
Pembangunan Daerah (ROA), dimoderasi oleh Good Corporate Governance yang terdiri dari ukuran dewan komisaris, komposisi dewan komisaris, frekuensi rapat, ukuran komite manajemen risiko dan ukuran komite audit. Sampel penelitian dalam penelitian ini terdiri dari 13 BPD yang terdaftar Se-indonesia pada periode penelitian 2009-2013 yang dipilih berdasarkan kriteria tertentu dengan menggunakan metode purposive sampling. Penelitian dari hasil yang dilakukan menunjukkan bahwa hanya penerapan manajemen risiko likuiditas (LDR) yang berpengaruh positif dan penerapan manajemen risiko Operasional (BOPO) yang berpengaruh negatif dan signifikan terhadap kinerja keuangan BPD (ROA), sementara penerapan manajemen risiko kredit meskipun memiliki pengaruh negatif terhadap variabel Return On Asset (ROA) dengan hasil koefisien regresi sebesar -0,091 tetapi tidak memiliki pengaruh yang signifikan terhadap variabel Return On Asset, sedangkan Good Corporate Governance yang terdiri dari ukuran dewan komisaris, komposisi dewan komisaris, frekuensi rapat, ukuran komite manajemen risiko dan ukuran komite audit (Izdihar, 2017).

Penelitian berikutnya bertujuan untuk meneliti sejauh mana perkembangan dan kemajuan penerapan manajemen risiko pada perbankan Syariah di Kota Ternate. Populasi dari penelitian ini adalah dua Bank Syariah yang ada di Kota Ternate yaitu: Bank Syariah Mandiri dan Bank Muamalat dan sampelnya adalah manajer dan staf tiap-tiap bank yang menangani manajemen risiko. Hasil penelitian ini menunjukan bahwa : (a). Pemahaman risiko dan manajemen risiko pada Bank Muamalat maupun Bank Syariah Mandiri kantor Cabang Ternate semuanya masuk dalam kategori baik. (b). praktek manajemen risiko pada bank Muamalat maupun Bank Syariah Mandiri kantor Cabang Ternate mayoritas menilai bahwa praktek manajemen risiko sudah masuk dalam kategori baik. Namun sebanyak 21,4\% di Bank Muamalat dan 13,3\% di Bank Syariah Mandiri menilai cukup. (c). Bank Muamalat maupun Bank Syariah Mandiri kantor Cabang Ternate menilai identifikasi risiko masuk dalam kategori baik. Namun sebanyak 7,1\% di Bank Muamalat 13,3\% di Bank Syariah Mandiri menilai cukup. (d). Bank Muamalat maupun Syariah Mandiri kantor Cabang Ternate mengatakan penilaian dan analisis risiko masuk dalam kategori baik. Namun sebanyak 28,6\% di Bank Muamalat dan 6,7\% pada Bank Syariah Mandiri yang menilai cukup. (e). Bank Muamalat maupun Bank Syariah Mandiri kantor cabang Ternate semuanya mengatakan baik tentang pelaksanaan monitoring dan pemantauan risiko (Pratama, 2018).

\section{METODE}

Kerangka teori merupakan kerangka penalaran yang terdiri dari konsep atau teori sebagai acuan penelitian(Nurdin \& Hartati, 2019). Biasanya kerangka teori disusun dalam bentuk matriks, diagram atau gambar sederhana. Berikut ini adalah proses penelitian kuantitatif yang terdiri dari beberapa proses seperti yang dijelaskan di bawah ini:

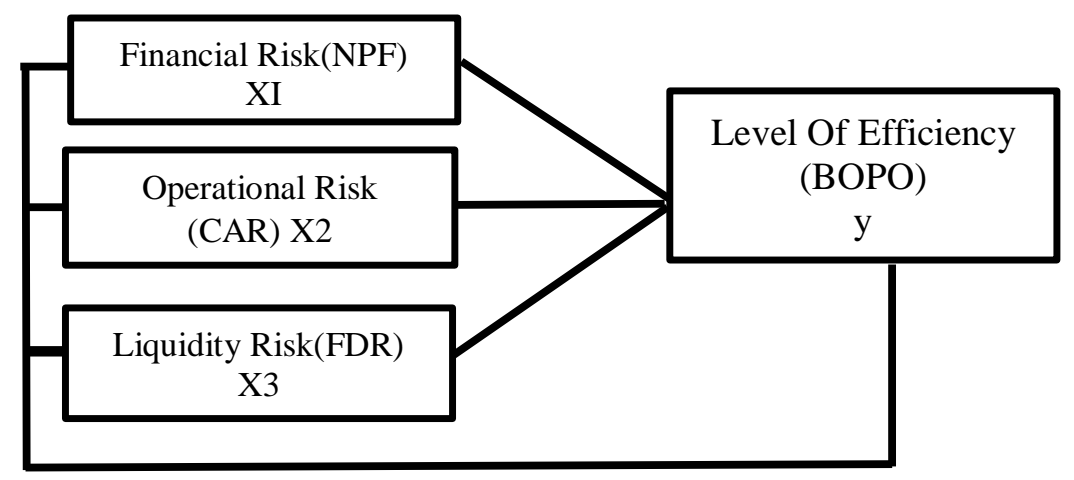

Gambar 1. Kerangka Teoritis

Sumber gambar :Data Riset, 2021

Kerangka penelitian pada Gambar 1, pendekatan yang digunakan adalah kuantitatif dengan format deskriptif, karena bertujuan untuk menjelaskan dan menceritakan berbagai situasi dan kondisi, atau berbagai variabel yang menjadi objek penelitian berdasarkan apa yang terjadi, dalam 
penelitian ini akan dibahas pengaruh risiko pembiayaan (X1), risiko operasional (X2), risiko likuiditas (X3) terhadap tingkat efisiensi (Y).

Referensi penelitian peneliti berupa buku, jurnal yang berkaitan dengan manajemen risiko pada tingkat efisiensi keuangan di Bank, regresi linier berganda untuk dijadikan kajian teoritis dalam penelitian.

Populasi adalah wilayah generalisasi yang terdiri atas objek / subjek yang mempunyai besaran dan karakteristik tertentu yang diterapkan oleh penelitian untuk dipelajari dan kemudian ditarik kesimpulannya. Jadi populasi dalam penelitian ini adalah Financial Quarterly (Maret, Juni, September dan Desember) 2015-2020 PT Bank DKI Jakarta(OJK, 2021).

Sampel adalah bagian dari jumlah dan karakteristik yang dimiliki oleh populasi tersebut. Dalam penelitian ini tidak diterbitkan laporan keuangan Triwulanan (Maret, Juni, September dan Desember) Bank DKI Jakarta periode 2015-2020, untuk laporan keuangan (Khasanah \& Pertiwi, 2010) triwulan Maret dan Desember 2016 tidak diterbitkan, triwulan September dan Desember tidak diterbitkan, yang berarti terdapat 20 sampel. Definisi operasional dilakukan agar tidak terjadi penyimpangan dalam membahas dan menganalisis permasalahan penelitian yang dilakukan. Definisi operasional variabel dalam penelitian ini adalah (Ridha, 2017):

Variabel terikat (dependent variable) adalah variabel yang nilainya dipengaruhi oleh variabel lain. Variabel terikat penelitian ini adalah tingkat efisiensi bank (Y), dalam penelitian ini variabel dependen diukur dengan Operational Expenditures from Operational Income (BOPO) yaitu jumlah level BOPO di PT Bank DKI Jakarta periode 2015-2020 yang diperoleh dari laporan keuangan Triwulanan (Maret, Juni, September dan Desember) PT Bank DKI Jakarta.

Variabel bebas (independent variable) adalah variabel yang nilainya tidak bergantung pada variabel lain, variabel independen dalam penelitian ini adalah

Sebuah. Risiko pembiayaan (X1). Yang dimaksud dengan risiko pembiayaan dalam penelitian ini adalah jumlah tingkat NPF pada PT Bank DKI Jakarta periode 2015-2020 yang diperoleh dari laporan keuangan triwulanan (Maret, Juni, September dan Desember) PT Bank DKI Jakarta.

Risiko operasional (X2). Risiko operasional didefinisikan sebagai total tingkat CAR pada PT Bank DKI Jakarta periode 2015-2020 yang diperoleh dari laporan keuangan triwulanan (Maret, Juni, September dan Desember) PT Bank DKI Jakarta.

Risiko likuiditas (X3). Yang dimaksud dengan risiko likuiditas adalah total tingkat FDR pada PT Bank DKI Jakarta periode 2015-2020 yang diperoleh dari laporan keuangan Triwulanan (Maret, Juni, September dan Desember) PT Bank DKI Jakarta.

Penelitian ini menggunakan metode data kuantitatif, dimana data yang digunakan dalam penelitian berupa angka dan perhitungan menggunakan metode statistik berbantuan program SPSS 21. Pengumpulan data bersumber dari lembaga keuangan OJK (Otoritas Jasa Keuangan) untuk laporan Publikasi di PT Bank DKI Jakarta Triwulan (Maret, Juni, September dan Desember) dari 2015 hingga 2020( $\underline{\mathrm{OJK}, 2021})$.

Tabel 1. Laporan Keuangan PT DKI Jakarta 2015-2020

\begin{tabular}{|l|l|l|l|l|l|}
\hline \multirow{2}{*}{ THN } & TRIWULAN & $\begin{array}{l}\text { Risiko } \\
\text { pembiayaan } \\
\text { NPF }\end{array}$ & $\begin{array}{l}\text { Risiko } \\
\text { operasional } \\
\text { CAR }\end{array}$ & $\begin{array}{l}\text { Risiko } \\
\text { likuiditas } \\
\text { FDR }\end{array}$ & $\begin{array}{c}\text { Belanja } \\
\text { Operasional dari } \\
\text { Pendapatan } \\
\text { Operasional } \\
\text { (BOPO) }\end{array}$ \\
\hline \multirow{4}{*}{2015} & MARET & 4.81 & 19.93 & 79.87 & 64.03 \\
\cline { 2 - 6 } & JUNI & 7.27 & 17.17 & 82.03 & 92.96 \\
\cline { 2 - 6 } & SEPTEMBER & 7,18 & 15.35 & 73.63 & 92.99 \\
\cline { 2 - 6 } & DESEMBER & 7.96 & 24.53 & 91.14 & 90.99 \\
\hline \multirow{2}{*}{2016} & JUNI & 7.77 & 28.51 & 89.56 & 79.25 \\
\cline { 2 - 6 } & SEPTEMBER & 7.60 & 29.27 & 82.99 & 80.26 \\
\hline \multirow{2}{*}{2017} & MARET & 5.37 & 30,47 & 72.82 & 78.25 \\
\cline { 2 - 6 } & JUNI & 4.73 & 28.80 & 72.07 & 77.91 \\
\hline
\end{tabular}


Owner: Riset \& Jurnal Akuntansi

e-ISSN : 2548-9224 |p-ISSN : 2548-7507

Volume 5 Nomor 2, Agustus 2021

DOI : https://doi.org/10.33395/owner.v5i2.425

\begin{tabular}{|l|l|l|l|l|l|}
\multirow{5}{*}{} & SEPTEMBER & 4.74 & 28.86 & 61.86 & 77.82 \\
\cline { 2 - 6 } & DESEMBER & 3.76 & 28.77 & 70.77 & 76.97 \\
\hline \multirow{4}{*}{2018} & MARET & 4.08 & 29.75 & 65.07 & 80.58 \\
\cline { 2 - 6 } & JUNI & 3.82 & 28.24 & 79.36 & 76.44 \\
\cline { 2 - 6 } & SEPTEMBER & 3.19 & 28.42 & 82.66 & 77.88 \\
\cline { 2 - 6 } & DESEMBER & 2.66 & 24.23 & 93.04 & 75.17 \\
\hline \multirow{4}{*}{2019} & MARET & 3.00 & 28.72 & 97.18 & 77.82 \\
\cline { 2 - 6 } & JUNI & 3.30 & 26.14 & 87.88 & 77.09 \\
\cline { 2 - 6 } & SEPTEMBER & 2.65 & 25.90 & 79.92 & 76.30 \\
\cline { 2 - 6 } & DESEMBER & 2.52 & 23.79 & 100.33 & 76.01 \\
\hline \multirow{2}{*}{2020} & MARET & 3.09 & 28.98 & 96.73 & 81.62 \\
\cline { 2 - 6 } & JUNI & 3.54 & 28.17 & 90.32 & 82.94 \\
\hline
\end{tabular}

Sumber tabel :(OJK, 2021)

Laporan keuangan pada Tabel 1, untuk publik adalah Triwulanan dari 2015 - 2020, dengan catatan tidak ada laporan Triwulanan Maret dan Desember 2016 dan Triwulan September dan Desember 2020, sehingga sampel yang diambil untuk mengolah datanya adalah $\mathrm{N}=20$.

\section{Analisis data}

Analisis data yang dilakukan oleh penelitian ini terhadap data tersebut adalah sebagai berikut:

Uji asumsi klasik

Uji asumsi klasik digunakan untuk mendapatkan model regresi yang menghasilkan estimator linier tidak biasa terbaik atau BLUE (Best Linear Un Estimator). BIRU dapat dicapai jika memenuhi asumsi klasik. Dalam penelitian uji asumsi klasik yang digunakan adalah uji normalitas, uji multikolonieritas, uji heteroskedastisitas, uji autokorelasi(Zainuddin, 2016).

\section{Uji Regresi Linier Berganda}

Analisis linier berganda digunakan untuk memprediksi bagaimana keadaan (naik turunnya) variabel dependen, ketika dua atau lebih variabel independen sebagai faktor prediktor dimanipulasi (kenaikan dan penurunan nilai)(Rahadjeng, 2017).

\section{Pengujian hipotesis}

\section{Uji Koefisien Determinan (R2)}

Koefisien determinasi digunakan untuk mengetahui persentase hubungan antara variabel bebas dan variabel terkait. Besarnya persentase pengaruh semua variabel terhadap nilai dependen ariable dapat dilihat dari besarnya koefisien determinan (R2) persamaan regresi(Manik, 2017).

\section{Uji Parsial (Uji t)}

Uji t digunakan untuk menguji apakah masing-masing variabel independen (independen) secara individual maupun individual berpengaruh signifikan terhadap variabel dependen (dependen) pada tingkat signifikan 0,05 (5\%) dengan asumsi variabel independen konstan(Azhari, 2020).

\section{Uji Simultan (Uji f).}

Uji f digunakan untuk mengetahui pengaruh risiko pembiayaan, risiko operasional dan risiko likuiditas terhadap tingkat efisiensi bank. Uji f pada dasarnya menunjukkan apakah semua variabel bebas atau bebas yang dimasukkan dalam model memiliki pengaruh bersama terhadap variabel terikat atau terikat. Pengujian dengan kriteria uji F tabel, jika Fhitung < Ftabel maka H0 diterima dan Ha ditolak artinya tidak signifikan dan jika Fhitung> Ftabel maka H0 ditolak dan Ha diterima, artinya signifikan(Danar Maharudin, 2019). 


\section{HASIL}

Pembahasan hasil penelitian meliputi beberapa tes, diantaranya sebagai berikut:

\section{Uji asumsi klasik}

\section{Uji normalitas}

Model regresi dikatakan berdistribusi normal, jika data ploting (titik-titik yang menggambarkan data sesungguhnya mengikuti garis diagonal

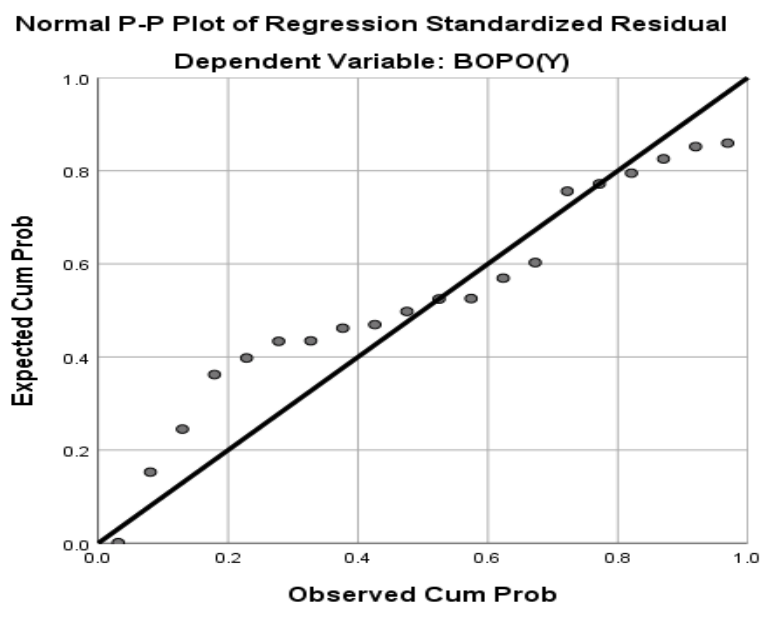

Sumber data : Data Riset,2021

Gambar 2. Uji Normalitas

Pengujian nomalitas gambar 2, Data ploting(titik-titik) yang menggambarkan data sesunggunya mengikuti garis normal, sehigga model regresi berdistribusi Normal.

Uji Multikolonieritas

Uji multikolonieritas merupakan pengujian untuk mengetahui ada tidaknya hubungan yang signifikan antara variabel independen dalam model regresi linier berganda. Pengujian ini diperlukan untuk mengetahui apakah ada variabel lain dalam satu model atau tidak. Kesamaan antar variabel independen dalam suatu model akan menyebabkan korelasi yang sangat kuat antara variabel independen dengan variabel independen lainnya.

Tabel 2. Uji Multikolonieritas

\begin{tabular}{|c|c|c|c|c|c|c|c|c|}
\hline \multicolumn{9}{|c|}{ Coefficients $^{\mathrm{a}}$} \\
\hline \multirow[t]{2}{*}{ Model } & & & & $\begin{array}{l}\text { Standardized } \\
\text { Coefficients }\end{array}$ & $\mathrm{t}$ & Sig. & $\begin{array}{l}\text { Collinearity } \\
\text { Statistics }\end{array}$ & \\
\hline & & & & Beta & & & Tolerance & VIF \\
\hline \multirow[t]{4}{*}{1} & (Constant) & 73,540 & 16,169 & & 4,548 & 0,000 & & \\
\hline & NPF(X1) & 1,830 & 0,757 & 0,524 & 2,419 & 0,028 & 0,853 & 1,172 \\
\hline & CAR(X2) & $-0,279$ & 0,331 & $-0,180$ & $\begin{array}{l}- \\
0,844\end{array}$ & 0,411 & 0,880 & 1,137 \\
\hline & FDR(X3) & 0,060 & 0,126 & 0,098 & 0,475 & 0,641 & 0,940 & 1,064 \\
\hline
\end{tabular}

Sumber tabel : Data Riset,2021

Jika dilihat dari tabel 2,. dapat disimpulkan bahwa nilai Variance Inflation Factor adalah 1,172 untuk variabel risiko pembiayaan (NPF), 1,137 untuk variabel risiko operasional (CAR) dan 1,064 untuk variabel risiko likuiditas (FDR) dan jumlah masing-masing variabel $<10$, dan nilai Toleransi untuk variabel risiko pembiayaan (NPF) 0,853 , untuk variabel risiko operasional (CAR) 0,880 , dan untuk variabel risiko likuiditas (FDR) 0,940. Jadi untuk variabel risiko pembiayaan, risiko operasional dan risiko likuiditas serta jumlah masing-masing variable > dari 0,1 maka model dapat 
Owner: Riset \& Jurnal Akuntansi

e-ISSN : 2548-9224 |p-ISSN : 2548-7507

Volume 5 Nomor 2, Agustus 2021

DOI : https://doi.org/10.33395/owner.v5i2.425

dikatakan bebas multikolinearitas.

\section{Uji Heteroskedastisitas}

Uji heteroskedastisitas adalah suatu kondisi dimana varians error confounding tidak konstan untuk semua nilai variabel independen, dimana pengujian ini bertujuan untuk menguji apakah model regresi tidak memiliki kesamaan varian residual atau observasi lainnya.

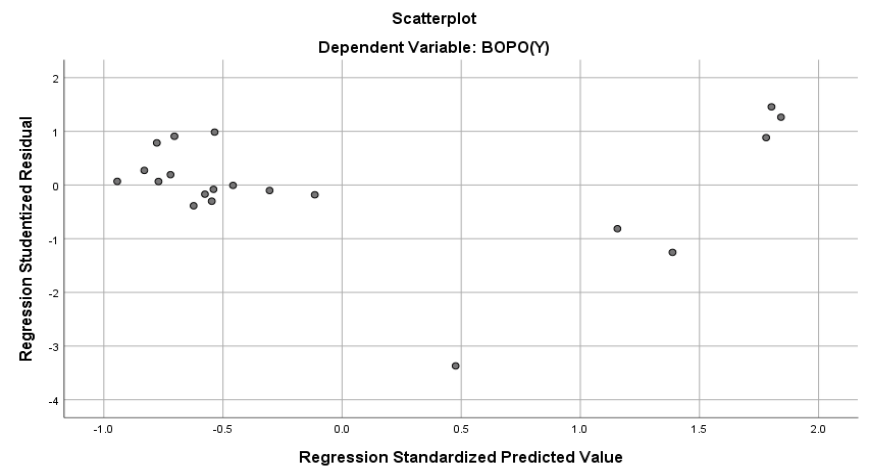

Gambar 3. Model Scatterplot

Sumber gambar : Data Riset,2021

Pengujian heteroskedastisitas Dari gambar 3, ciri-ciri citra model scatterplot adalah:

Titik data tersebar di atas dan di bawah atau di sekitar 0 . Titik data tidak hanya menggumpal ke atas atau ke bawah. Titik penyebaran data tidak boleh membentuk pola bergelombang yang melebar kemudian menyempit dan melebar kembali. Distribusi titik data tidak boleh berpola.

Pengujian dapat disimpulkan bahwa karakteristik terpenuhi sehingga dapat dikatakan bahwa dalam model regresi pengaruh risiko pembiayaan, risiko operasional dan risiko likuiditas terhadap tingkat efisiensi bank tidak terjadi heteroskedastisitas sehingga dalam uji asumsi klasik heteroskedastisitas terpenuhi, selanjutnya dalam hal ini dapat dilanjutkan ke tahap pengujian regresi linier berganda.

\section{Uji Autokorelasi}

Uji autokorelasi digunakan untuk melihat apakah terdapat hubungan linier atau kesalahan dalam rangkaian pengamatan yang diurutkan menurut waktu (data deret waktu). Pengujian ini dilakukan jika data yang dianalisis adalah data deret waktu, untuk melihat apakah ada permasalahan autokorelasi. Pengujian yang sering digunakan adalah tes Durbin-Waston (DW test). Selain menggunakan uji Durbin-Waston, dapat juga digunakan uji korelasional seri Breusch Goldfrey pada Uji LM. Langkah-langkah pengujiannya adalah sebagai berikut:

Hipotesa

H0: Model memiliki autokorelasi

Ha: Model tidak memiliki autokorelasi

Jika probabilitas > Alpha $(0,05)$ maka H0 ditolak, maka Ha diterima

Jika probabilitas < Alpha $(0,05)$ maka Ha ditolak maka H0 diterima

Tabel 3. Model Summary

\begin{tabular}{|c|c|c|c|c|c|}
\hline \multicolumn{6}{|c|}{ Model Summary ${ }^{b}$} \\
\hline Model & $\mathrm{R}$ & $\begin{array}{l}\mathrm{R} \\
\text { Square }\end{array}$ & $\begin{array}{l}\text { Adjusted } \\
\mathrm{R} \\
\text { Square }\end{array}$ & $\begin{array}{l}\text { Std. } \\
\text { Error of } \\
\text { the } \\
\text { Estimate }\end{array}$ & $\begin{array}{l}\text { Durbin- } \\
\text { Watson }\end{array}$ \\
\hline 1 & $.599^{\mathrm{a}}$ & 0,359 & 0,239 & 5,75575 & 1,481 \\
\hline \multicolumn{6}{|c|}{ a. Predictors: (Constant), FDR(X3), CAR(X2), NPF(X1) } \\
\hline \multicolumn{6}{|c|}{ b. Dependent Variable: BOPO(Y) } \\
\hline
\end{tabular}

Sumber tabel : Data Riset,2021 
Pengujian autokorelasi dari tabel 3, untuk nilai du dicari distribusi nilai tabel durbin Watson berdasarkan $\mathrm{k}$ (3) dan $\mathrm{N}=20$ dengan signifikansi 5\%, kemudian du (1.6763) < Durbin Watson $(1,481)<4$-du $(2,324)$ dapat disimpulkan bahwa tidak ada kepastian ada atau tidaknya gejala autokorelasi, maka solusi yang diperlukan untuk mengatasi gejala autokorelasi, dilakukan dengan Uji Run test.

Landasan Uji Run Test sebagai berikut :

Jika nilai Asymp.Sig(2-tailed) lebih kecil dari 0,05 maka terdapat gejala autokorelasi Jika nilai Asymp.Sig(2-tailed) lebih besar dari 0,05 maka tidak terdapat gejala autokorelasi.

Tabel 4. Uji Run Test

\begin{tabular}{|l|l|}
\hline & $\begin{array}{l}\text { Unstandardized } \\
\text { Residual }\end{array}$ \\
\hline Test Value $^{\mathrm{a}}$ & 0,16003 \\
\hline Cases < Test Value & 10 \\
\hline Cases > = Test Value & 10 \\
\hline Total Cases & 20 \\
\hline Number of Runs & 12 \\
\hline Z & 0,230 \\
\hline Asymp. Sig. (2-tailed) & 0,818 \\
\hline a. Median & \\
\hline
\end{tabular}

Sumber tabel : Data Riset,2021

Pengujian run test pada tabel 4, nilai Asymp.Sig(2-tailed) 0,818>0,05 maka dapat disimpulkan tidak terdapat gejala autokorelasi.

Uji Regresi Linier Berganda

Analisis linier berganda digunakan untuk memprediksi bagaimana keadaan (naik turunnya) variabel dependen, ketika dua atau lebih variabel independen sebagai faktor prediktor dimanipulasi (kenaikan dan penurunan nilai).

Tabel 5. Uji Regresi Linier Berganda

\begin{tabular}{|c|c|c|c|c|c|c|c|c|}
\hline \multicolumn{9}{|c|}{ Coefficients $^{\mathrm{a}}$} \\
\hline \multirow[t]{2}{*}{ Model } & & & & \multirow{2}{*}{\begin{tabular}{|l} 
Standardized \\
Coefficients
\end{tabular}} & \multirow[t]{2}{*}{$\mathrm{t}$} & \multirow[t]{2}{*}{ Sig. } & $\begin{array}{l}\text { Collinearity } \\
\text { Statistics }\end{array}$ & \\
\hline & & & & & & & Tolerance & VIF \\
\hline 1 & (Constant) & 73,540 & 16,169 & & 4,548 & 0,000 & & \\
\hline & NPF(X1) & 1,830 & 0,757 & 0,524 & 2,419 & 0,028 & 0,853 & 1,172 \\
\hline & CAR(X2) & $-0,279$ & 0,331 & $-0,180$ & $-0,844$ & 0,411 & 0,880 & 1,137 \\
\hline & FDR(X3) & 0,060 & 0,126 & 0,098 & 0,475 & 0,641 & 0,940 & 1,064 \\
\hline
\end{tabular}

Sumber tabel : Riset Data,2021

Pengujian regresi linier berganda pada Tabel 5, dari perhitungan menggunakan SPSS diperoleh hasil sebagai berikut:

$\mathrm{a}=73.540, \mathrm{~b}=1.830, \mathrm{~b} 2=-0,279, \mathrm{~b} 3=0,060$

Berdasarkan rumus persamaan regresi linier berganda diperoleh hasil analisis sebagai berikut:

$\mathrm{Y}=73.540+\{(1.830) \mathrm{X} 1+(-0.279) \mathrm{X} 2+(0,060) \mathrm{X} 3\}$

Model persamaan regresi berganda signifikan:

Nilai analisis regresi linier berganda yang masih berupa angka dapat dijelaskan dalam bahasa yang mudah dipahami sebagai berikut: 
Nilai $\alpha$ sebesar 73.540 artinya jika variabel risiko pembiayaan (X1) risiko operasional (X2) dan risiko likuiditas (X3) konstan atau tidak berubah (sama dengan nol, maka tingkat efisiensi (Y) akan menjadi senilai 73.540.

Nilai koefisien regresi X1 $=1.830$ menunjukkan bahwa jika risiko pembiayaan meningkat $100 \%$ maka akan mengakibatkan peningkatan tingkat efisiensi pada PT Bank DKI Jakarta sebesar 1.830 .

Nilai koefisien regresi $\mathrm{X} 2=-0.279$ menunjukkan bahwa jika risiko pembiayaan mengalami peningkatan sebesar $100 \%$ maka akan mengakibatkan peningkatan tingkat efisiensi pada PT Bank DKI Jakarta sebesar -0.279.

Nilai koefisien regresi X3 $=0,060$ menunjukkan bahwa apabila risiko pembiayaan mengalami peningkatan sebesar $100 \%$ maka akan mengakibatkan peningkatan tingkat efisiensi pada PT Bank DKI Jakarta sebesar 0,060.

\section{Pengujian hipotesis}

\section{Uji Koefisien Determinan (R2)}

Koefisien determinasi digunakan untuk mengetahui persentase hubungan antara variabel bebas dan variabel terikat. Besarnya persentase pengaruh semua variabel terhadap nilai variabel dependen dapat dilihat dari koefisien determinan (R2) persamaan regresi. Koefisien determinasi dilihat dari hasil perhitungan SPSS sebagai berikut:

Tabel 6. Uji Koefisien Determinan(R2)

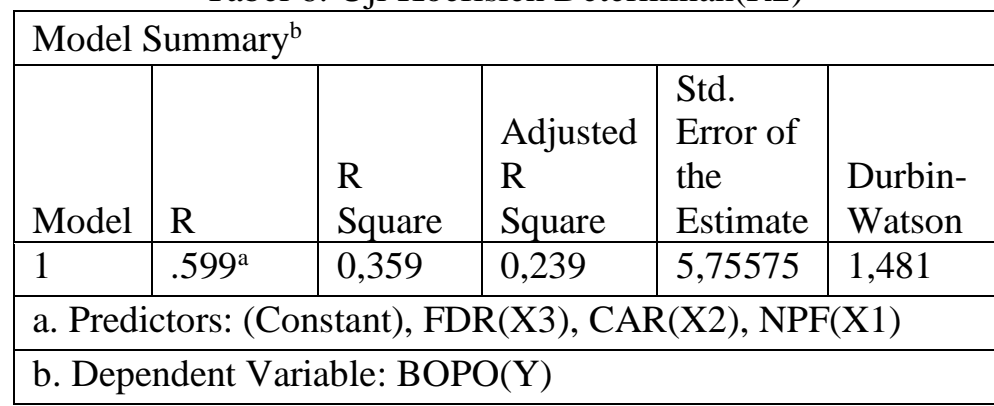

Sumber tabel : Data Riset,2021

Dilihat dari tabel 6 koefisien determinan (R2) menunjukkan angka Adjusted R Square sebesar 0,359 atau 35,9\% yang berarti variasi tingkat efisiensi dapat dijelaskan oleh risiko pembiayaan, risiko operasional dan risiko likuiditas, sisanya $64,1 \%$ dapat dijelaskan dari variabel lain di luar. variabel penelitian.

\section{Uji Parsial (Uji t)}

Uji t digunakan untuk menguji apakah masing-masing variabel independen (independen) secara individual maupun individual memiliki pengaruh yang signifikan terhadap variabel dependen pada tingkat signifikan 0,05 (5\%) dengan asumsi variabel bebas independen konstan.

Tabel 7. Uji Parsial(Uji t)

\begin{tabular}{|c|c|c|c|c|c|c|c|c|}
\hline \multicolumn{9}{|c|}{ Coefficients ${ }^{\mathrm{a}}$} \\
\hline \multirow[t]{2}{*}{ Model } & & & & $\begin{array}{l}\text { Standardized } \\
\text { Coefficients }\end{array}$ & $\mathrm{t}$ & Sig. & $\begin{array}{l}\text { Collinearity } \\
\text { Statistics }\end{array}$ & \\
\hline & & & & Beta & & & Tolerance & VIF \\
\hline 1 & (Constant) & 73,540 & 16,169 & & 4,548 & 0,000 & & \\
\hline & NPF(X1) & 1,830 & 0,757 & 0,524 & 2,419 & 0,028 & 0,853 & 1,172 \\
\hline & CAR(X2) & $-0,279$ & 0,331 & $-0,180$ & $-0,844$ & 0,411 & 0,880 & 1,137 \\
\hline & FDR(X3) & 0,060 & 0,126 & 0,098 & 0,475 & 0,641 & 0,940 & 1,064 \\
\hline
\end{tabular}

a. Dependent Variable: BOPO(Y) 
Sumber tabel : Data Riset,2021

Pengujian parsial pada Tabel 7, dapat dilihat dengan melihat hasil koefisien keluaran SPSS pada uji-t di atas dengan membandingkan t hitung dengan t tabel 2.1199 yang diperoleh dari t tabel dengan $\mathrm{df}=\mathrm{nk}(20-4)$ yaitu 16 dan alpha 0,05 , untuk melihat secara parsial pengaruh risiko pembiayaan terhadap tingkat efisiensi pada PT Bank DKI Jakarta, maka analisisnya sebagai berikut:

Pengaruh risiko pembiayaan (X1) terhadap tingkat efisiensi (Y) dari hipotesis:

H0: Risiko pembiayaan parsial tidak berpengaruh signifikan terhadap tingkat efisiensi PT Bank DKI Jakarta.

Ha: risiko pembiayaan secara parsial berpengaruh positif signifikan terhadap tingkat efisiensi PT Bank DKI Jakarta.

Berdasarkan hasil uji t untuk variabel risiko pembiayaan diperoleh thitung 2.419 dan ttabel 2,1199 dengan nilai signifikan $0,028<0,05$ sehingga $\mathrm{H} 0$ ditolak dan Ha diterima. Hal ini menunjukkan bahwa risiko pembiayaan berpengaruh positif signifikan secara parsial terhadap tingkat efisiensi PT Bank DKI Jakarta.

Pengaruh risiko operasional (X2) terhadap tingkat efisiensi (Y) hipotesis:

H0: Risiko operasional secara parsial tidak berpengaruh signifikan terhadap tingkat efisiensi PT Bank DKI Jakarta.

Ha: Risiko operasional secara parsial berpengaruh positif signifikan terhadap tingkat efisiensi PT Bank DKI Jakarta.

Berdasarkan hasil uji $t$ untuk variabel risiko operasional diperoleh $t_{\text {hitung }}-0,844$ dan $t_{\text {tabel }} 2,1199$ dengan nilai signifikansi 0,411>0,05 sehingga H0 diterima dan Ha ditolak. Hal ini menunjukkan bahwa risiko operasional tidak berpengaruh negatif signifikan secara parsial terhadap tingkat efisiensi PT Bank DKI Jakarta.

Pengaruh Risiko Likuiditas (X3) terhadap Tingkat Efisiensi (Y) Hipotesis: H0: Secara parsial Risiko Likuiditas tidak berpengaruh signifikan terhadap Tingkat Efisiensi PT Bank DKI Jakarta.

Ha: Risiko likuiditas secara parsial berpengaruh signifikan terhadap tingkat efisiensi PT Bank DKI Jakarta.

Berdasarkan hasil uji t untuk variabel risiko likuiditas diperoleh t hitung 0,475 dan $\mathrm{t}$ tabel 2,1199 dengan nilai signifikansi 0,389<0,05, maka H0 diterima dan Ha ditolak. Hal ini menunjukkan bahwa risiko likuiditas tidak berpengaruh positif signifikan secara parsial terhadap tingkat efisiensi PT Bank DKI Jakarta.

\section{Uji Simultan (Uji F)}

Uji f digunakan untuk mengetahui pengaruh risiko pembiayaan, risiko operasional dan risiko likuiditas terhadap tingkat efisiensi bank. Uji f pada dasarnya menunjukkan apakah semua variabel bebas atau bebas yang dimasukkan dalam model memiliki pengaruh bersama terhadap variabel terikat atau terikat.

Dengan kriteria uji $\mathrm{F}$ tabel, jika $\mathrm{F}_{\text {hitung }}<\mathrm{F}_{\text {tabel }}$ maka $\mathrm{H} 0$ diterima dan Ha diterima, artinya tidak signifikan dan jika Fhitung > Ftabel maka H0 ditolak dan Ha diterima, artinya signifikan.

Tabel 8. Uji Simultan (Uji f)

\begin{tabular}{|l|l|l|l|l|l|l|}
\hline \multicolumn{7}{|c|}{ ANOVAa } \\
\hline Model & & $\begin{array}{l}\text { Sum of } \\
\text { Squares }\end{array}$ & df & $\begin{array}{l}\text { Mean } \\
\text { Square }\end{array}$ & F & Sig. \\
\hline 1 & Regression & 297,132 & 3 & 99,044 & 2,990 & $.062 b$ \\
\hline & Residual & 530,058 & 16 & 33,129 & & \\
\hline
\end{tabular}




\begin{tabular}{|l|l|l|l|} 
& Total $|827,191| 19$ & & \\
\hline a. Dependent Variable: BOPO(Y) \\
\hline b. Predictors: (Constant), FDR(X3), CAR(X2), NPF(X1) \\
\hline
\end{tabular}

Sumber Tabel : Data Riset,2021

Pengujian simultan pada tabel 8, dari uji ANOVA atau uji F diperoleh nilai Fhitung 2,990 > F tabel 2,1199 dengan tingkat signifikan 0,062 , karena probabilitasnya signifikan maka jauh lebih kecil dari 0,05 sehingga $\mathrm{H} 0$ diterima dan Ha ditolak. Hal ini menunjukkan bahwa secara simultan tidak terdapat pengaruh yang signifikan pada resiko pembiayan bersama terhadap tingkat efisiensi pada PT Bank DKI Jakarta.

\section{PEMBAHASAN}

Hasil dari penelitian menunjukkan bahwa risiko pembiayaan(X1) berpengaruh positif signifikan secara parsial terhadap tingkat efisiensi(Y), resiko risiko operasional(X2) tidak berpengaruh negatif signifikan secara parsial terhadap tingkat efisiensi(Y), dan risiko likuiditas(X3) tidak berpengaruh positif signifikan secara parsial terhadap tingkat efisiensi(Y), untuk pengarug secara simultan tidak terdapat pengaruh yang signifikan pada resiko pembiayan bersama terhadap tingkat efisiensi. Tingkat pengaruh variable $\mathrm{X} 1, \mathrm{X} 2, \mathrm{X} 3$ terhadap $\mathrm{Y}$ pada koefisien determinan (R2) menunjukkan angka Adjusted R Square sebesar 0,359 atau 35,9\% yang berarti variasi tingkat efisiensi dapat dijelaskan oleh risiko pembiayaan, risiko operasional dan risiko likuiditas, sisanya $64,1 \%$ dapat dijelaskan dari variabel lain di luar, untuk Penelitian terkait sebelumnya tidak terjadi kesamaan dalam pengaruh nilai independent $(\mathrm{x})$ dan nilai dependent $(\mathrm{Y})$, karena perbedaan dalam nilai yang dihasilkan dari data Pengolahan SPSS. Kemungkinan terjadi juga pada penelitian yang dilakukan oleh penulis karena tidak lengkapnya data yang didapat dari sumber ojk.go.id untuk laporan Triwulan Maret,Desember 2016 dan Triwulan September, Desember 2020 sehingga nilai ketepatan analisis data SPSS tidak maksimal. Ada kesempatan untuk melakukan penelitian kembali untuk melengkapi nilai-nilai triwulan di tahun 2016 dan 2020.

\section{KESIMPULAN}

Tingkat pengaruh nilai variable bebas (Risiko pembiayaan, Risiko operasional dan Risiko Likuiditas) hanya 35,9\% dari variable terkait(Tingkat efisiensi ) sisanya 64,1\% dari variabel lain yang belum masuk dalam penelitian tersebut. Pengaruh secara parsial positif pada variabel bebas (risiko pembiayaan) terhadap variabel terkait(tingkat efisiensi), variabel bebas (risiko operasional) tidak berpengaruh negative terhadap variabel terkait(tingkat efisiensi) dan untuk variabel bebas (risiko likuiditas) tidak berpengaruh positif pada variabel terkait(tingkat efisiensi).

\section{REFERENSI}

Alimusa, L. O., \& Murini. (2018). PENGARUH INTERNAL CAPITAL ADEQUENCY RATIO (CAR), FINANCING TO DEPOSIT RATIO (FDR), DAN BIAYA OPERASIONAL PER PENDAPATAN OPERASIONAL (BOPO) DALAM PENINGKATAN PROFITABILITAS INDUSTRI BANK SYARIAH DI INDONESIA. Jurnal Mega Aktiva, 7(April), 1-10.

Amalina, A., \& Saifi, M. (2018). Analisis Sistem Akuntansi Pemberian Kredit Multiguna Sebagai Salah Satu Upaya Meminimalisir Kredit Bermasalah. Jurnal Administrasi Bisnis, 60(2), 1927.

Azhari. (2020). Pengaruh Kompetensi, Independensi, Dan Profesionalisme Auditor Terhadap Kualitas Audit Dengan Etika Auditor Sebagai Variabel Moderasi. Invoice: Jurnal Ilmu Akuntansi, 2(2), 139-184. https://doi.org/10.26618/inv.v2i2.4116

Chosyali, A., \& Sartono, T. (2019). Optimalisasi Peningkatan Kualitas Kredit Dalam Rangka $\begin{array}{lllll}\text { Mengatasi Kredit } \quad \text { Bermasalah. } & 98 .\end{array}$ https://doi.org/10.14710//r.v15i1.23357

Danar Maharudin, A. (2019). Efisiensi Perbankan Syariah Di Indonesia. JEJAK: Jurnal Ekonomi Dan Kebijakan, 7(2), 1-11. https://doi.org/10.15294/jejak.v7i2.3895

DKI, team B. (2021). Bank DKI.

Eprianti, N. (2019). Penerapan Prinsip 5C Terhadap Tingkat Non Performing Financing (Npf). 


\section{Amwaluna: Jurnal Ekonomi Dan Keuangan Syariah, 3(2).} https://doi.org/10.29313/amwaluna.v3i2.4645

Handa Gustiawan. (2019). Pengaruh Dana Pihak Ketiga, Non Performing Financing, Dan Capital Adequacy Ratio Terhadap Financing To Deposit Ratio Pada PT.Bank Maybank Syariah Indonesia Periode 2011-2018. $A \gamma \alpha \eta, 8(5), 55$.

Izdihar, S. (2017). Pengaruh Penerapan Manajemen Risiko Terhadap Kinerja Keuangan Dengan Dimoderasi Good Corporate Governance (Studi Empiris Pada BPD Se-Indonesia Tahun 2009-2013 ). JURNAL EKONOMI, 25, 1-14.

Kansil, D., Murni, S., Tulung, J. E., Risiko, P., Kansil, D., Murni, S., ... Roa, B. (2017). Pengaruh Risiko Perbankan Terhadap Kinerja Keuangan Tahun 2013-2015 (Bank Pembangunan Daerah Se-Indonesia). Jurnal EMBA: Jurnal Riset Ekonomi, Manajemen, Bisnis Dan Akuntansi, 5(3), 3508-3517. https://doi.org/10.35794/emba.v5i3.17581

Khasanah, I., \& Pertiwi, O. D. (2010). terhadap Kepuasan Konsumen RS St . Elisabeth Semarang. Jurnal Khasanah Pertiwi, 12(2), 117-124.

Manik, S. (2017). Pengaruh Kepuasan Kerja Terhadap Disiplin Kerja Pegawai Kantor Camat Pendalian Iv Koto Kabupaten Rokan Hulu. International Journal of Social Science and Business, 1(4), 257. https://doi.org/10.23887/ijssb.v1i4.12526

Mukhlishin, A., \& Suhendri, A. (2018). Analisa Manajemen Risiko (Kajian Kritis Terhadab Perbankan Syariah di Era Kontemporer). An-Nisbah: Jurnal Ekonomi Syariah, 5(1), 257-275. https://doi.org/10.21274/an.2018.5.1.257-275

Nazir. (2018). The Effect of Risk Management Implementation on Financial Performance Satisfaction at Regional Development Banks in Indonesia. Jurnal Visioner \& Strategis, 7(1), $41-50$.

Nurdin, I., \& Hartati, S. (2019). Metodologi Penelitan Sosial. Retrieved from https://play.google.com/store/books/details?id=tretDwAAQBAJ\&rdid=book-

tretDwAAQBAJ\&rdot=1\&source=gbs_vpt_read\&pcampaignid=books_booksearch_viewpo $\mathrm{rt}$

OJK, T. (2021). Otoritas jasa Keuangan. Retrieved from web page website: https://www.ojk.go.id/id/Default.aspx

Pratama, R. (2018). PENERAPAN MANAJEMEN RISIKO PADA PERBANKAN SYARIAH (Studi Kasus Pada Bank Muamalat \& Bank Syariah Mandiri Cabang Kota Ternate). Jurnal Mitra Manajemen, 2(6), 597-609. https://doi.org/10.52160/ejmm.v2i6.162

Rahadjeng, E. R. (2017). "Pengaruh Perputaran Piutang dan Pengumpulan Piutang Terhadap Likuiditas Perusahaan Otomotif dan Komponen yang Tercatat di Bursa Efek Indonesia.” Seminar Nasional Dan Gelar Produk, 1094-1103.

Riau, B. (2017). Kajian Ekonomi dan Keuangan Regional Provinsi Kepulauan Riau Mei 2017. Bank Indonesia Kantor Wilayah Kepulauan Riau, 1-83.

Ridha, N. (2017). Proses Penelitian, Masalah, Variabel, dan Paradigma Penelitian. Jurnal Hikmah, 14(1), 62-70. Retrieved from http://jurnalhikmah.staisumateramedan.ac.id/index.php/hikmah/article/download/10/13

Senduk, N., Willar, D., \& Manoppo, F. (2016). Modeling Of Project Risk Management In SmallScale Construction Services Providing Companies (Contractor Case Study in Manado). Jurnal Ilmiah Media Engineering, 6(2), 96924.

Sukamto. (2016). Formulasi Strategi Kebijakan Pemberdayaan Ekonomi Rakyat Kabinet Indonesia Kerja Dalam Prespektif Ekonomi Islam. Jurnal MALIA, 7, 185-212.

Suwinardi. (2016). Manajemen risiko proyek. Orbith, 12(manajemen resiko proyek), 145-151.

Zainuddin. (2016). Pengaruh car, bopo, dan npf terhadap profitabilitas (roa) pada pt. Bank Rakyat Indonesia Syariah (Bri Syariah). Retrieved from IAIN Padang Sidempuan website: http://etd.iain-padangsidimpuan.ac.id/687/ 